\title{
ELANE wt Allele
}

National Cancer Institute

\section{Source}

National Cancer Institute. ELANE wt Allele. NCI Thesaurus. Code C104196.

Human ELANE wild-type allele is located in the vicinity of 19p13.3 and is approximately 4 $\mathrm{kb}$ in length. This allele, which encodes neutrophil elastase protein, is involved in innate host defense and tissue remodeling. 